\title{
Deconstructing the substantialist conception of God: recasting Heidegger's critique of Augustine
} Desconstruindo a concepção substancialista de Deus:
reformulando a crítica de Heidegger de Agostinho

*Nythamar de Oliveira

\begin{abstract}
In this paper, I argue that Augustine's conception of God as substance (substantia) has misleadingly been evoked by Martin Heidegger's deconstruction of onto-theological and substantialist variants of metaphysics as they mistook entities (Seienden, entia, beings) for their very Being (Sein, ens, esse) which cannot be conceptualized or objectified by human thinking, but makes both their thought and reality possible. Even though Augustine sought somehow to reconcile a Neoplatonic, essentialist cosmology with a Judeo-Christian worldview of historical redemption, Heidegger not only failed to properly recognize his indebtedness to Augustinian existential anthropology, but also the latter's contention that the actuality of beings and contingent history ultimately determines ontological concepts in their basic difference from their ontical counterparts, compromising thus Heidegger's intuitive criticisms against the confusion between God and Being (Sein).
\end{abstract}

Keywords: being; essence; God; metaphysics; ontology; substance.

Resumo: Neste artigo, argumento que a concepção de Deus como substância (substantia) tem sido invocada de forma equivocada pela desconstrução heideggeriana de variantes onto-teológicas e substancialistas da metafísica, na medida em que confundiram entidades (Seienden, entia, entes) com seu próprio Ser (Sein, Ens, esse), que não pode ser conceitualizado ou objetivado pelo pensamento humano, mas torna possível o seu pensamento e realidade. Apesar de Agostinho ter procurado de alguma forma conciliar uma cosmologia essencialista neoplatônica com uma cosmovisão judaico-cristã da redenção histórica, Heidegger não apenas deixa de reconhecer adequadamente seu endividamento quanto à antropologia existencial

* PPGF/PUCRS <nythamar.oliveira@pucrs.br> 
agostiniana, mas também a afirmação deste último de que a realidade dos entes e da história contingente determina, em última análise, os conceitos ontológicos em sua diferença fundamental de suas contrapartes ônticas, comprometendo destarte as críticas intuitivas de Heidegger contra a confusão entre Deus e Ser (Sein).

Palavras-chave: ser; essência; Deus; metafísica; ontologia; substância.

\section{Introduction}

7 The magnificent impact of Aurelius Augustinus's writings upon Western $\perp$ theological and philosophical traditions is a fait accompli which no one has dared to call into question. What has become questionable, however, following Martin Heidegger's radical hermeneutic critique of Western thought, is the decisive role played by Augustine's metaphysics in the fateful oblivion of Being in the history of philosophy. According to Heidegger, Western philosophy has failed to articulate the question of the meaning of Being (die Seinsfrage) precisely because classic ontology mistook entities (Seienden, beings) for their very Being (das Sein) which cannot be conceptualized or objectified by human thinking, but makes both thought and reality possible. ${ }^{1}$ (Heidegger, 1986, 39f.) Both Platonism and Christian metaphysics were found guilty of reducing the ontological difference (between Being and beings) to its ontic manifestation in the phenomenal world. According to Heidegger, Christianity decisively contributed to this metaphysical "oblivion of Being" by maintaining the primacy of a transcendent being over its created beings, among which homo ("man") $)^{2}$, the imago dei, is to rationally reflect such an essential order of creation. In a famous passage from his epoch-making Sein und Zeit (1927), Heidegger quotes from the Confessions to contrast an ontically-determined metaphysics with the phenomenological, hermeneutical ontology of his revolutionary project:

When Augustine asks: "Quid autem propinquius meipso mihi?" and must answer: "ego certe laboro hic et laboro in meipso: factus sum mihi terra difficultatis et sudoris nimii," [Confessiones X, xvi,] this applies not only to the ontical and pre-ontological opaqueness of Dasein but even more to the ontological task which lies ahead; for not only must this entity not to be missed in that kind of Being in which it is phenomenally closest, but it must be made accessible by a positive characterization (Heidegger, 1986, 43f.).

1 I am using the 16th edition of the original text and Macquarrie \& Robinson's translation. Page numbers refer to the German edition text, also used in the English edition.

2 Whenever the word "man" occurs, it has been used in the gender-neutral sense of homo (German, Mensch). 
And Heidegger goes on to distinguish his Daseinsanalytik from the classic, metaphysical approaches developed by anthropology, psychology, and biology. Above all, Heidegger's hermeneutics set out to break away from the traditional problematics defined by what has been called "philosophical anthropology," which sought to articulate the ontological question in terms of the humanum ("what makes humans human?"). According to Heidegger, both humanistic anthropology and Christian theology have been caught up in the hermeneutic impasse of their very conceptualization of "transcendence" in function of an essentialist or substantialist definition of "man" as animal rationale and imago dei, respectively. Commenting on the latter, Heidegger quotes from $B^{\prime}$ reshit, the first book of the Torah in the Vulgate edition:

\begin{abstract}
"Faciamus hominem ad imaginem nostram et similitudinem" [Gen 1:26]. With this as its point of departure, the anthropology of Christian theology, taking with it the ancient definition, arrives at an interpretation of that entity which we call "man". But just as the Being of God gets Interpreted ontologically by means of the ancient ontology, so does the Being of the ens finitum, and to an even greater extent, its finite substance in a body-soul composite. In modern times the Christian definition has been deprived of its theological character. But the idea of "transcendence" - that human being is something that reaches beyond herself- is rooted in Christian dogmatics, which can hardly be said to have made an ontological problem of human's Being (Heidegger, 1986, 48f.).
\end{abstract}

Although I do not intend to elaborate on a critical study of Heidegger's Destruktion der Onto-Theologie vis-à-vis Augustine's doctrina christiana, I shall recast this topic by situating it within the broader framework of a philosophical hermeneutics, without exploring the implications for an existential philosophy of time, facticity, and historicity, even though Augustine's philosophical theology entails all these elements, particularly in Heidegger's de-theologizing reading (Enttheologisierung) of Augustine and the former's conception of Dasein as care (Sorge) (Heidegger, 1986, 199; Zarader, 1990; Coyne, 2015, 244 n. 20; von Herrmann, 2008). Besides Sein und Zeit, several of Heidegger's published volumes of his monumental Gesamtausgabe attest to his indebtedness to Augustine, especially volumes 1 (Frühe Schriften, 1912-1916), 17 (Einführung in die phänomenologische Forschung, Winter semester 1923/24), 20 (Prolegomena zur Geschichte des Zeitbegriffs, Summer semester 1925), 24 (Die Grundprobleme der Phänomenologie, Summer semester 1927), 60 (Phänomenologie des religiösen Lebens, 2. Augustinus und der Neuplatonismus, Summer semester 1921), 64 (Der Begriff der Zeit, 1924), 80 (Vorträge; Augustinus: Quid est tempus? Confessiones lib. XI, 
Vortrag in Beuron 26. Oktober 1930), and 83 (Seminare: Platon-AristotelesAugustinus, Winter semester 1930/31). On the other hand, it has simply become impossible to do theology today without questioning anew the appropriation of Greek philosophy by Christian theologians, not to mention their explicit, controversial, and often hidden indebtedness to Jewish thought, especially during the long period of history know as the Middle Ages. Since one might be tempted to contrast the Augustinian conception of God as substantia in De Trinitate with the personal, experiential God of his Confessiones, the ontological implications of his theo-logy proper defines our problematic as a hermeneutical one. Heidegger's critique of Western metaphysics and its subsequent program of "deconstruction" have helped us, in effect, to re-evaluate our own understanding of Christian doctrines and their theological development. Of course, Heidegger's understanding of biblical texts and Christian theology is itself to be critically "deconstructed" —and this has been done by fine Continental thinkers such as Hans Jonas, Emmanuel Levinas, Etienne Gilson, Paul Ricoeur, Jacques Derrida, and Jean-Luc Marion, to name but a few. I am particularly indebted to the seminal works of John Caputo, Ze'ev Levy, Joseph O'Leary, and Marlène Zarader, whose responsible deconstruction of onto-theological metaphysics has opened up new horizons for the dialogue between theology and philosophy in light of the Judeo-Christian tradition. Although I won't be further exploring this issue here, I believe that one of Heidegger's most brilliant students, Hannah Arendt, offered a reading of Augustine's ethics that better accounts for the intersubjective, social dimension of caritas and solidarity, which seems to be eclipsed in the Heideggerian accounts of Mitdasein and Mitsein: social, ethical praxis ought to be prior to all theoria and poiesis, even before techniques (technai) are deployed and employed, in a Heideggerian sense, in theorizing what is at hand, given in theoretical and scientific approaches to beings (Vorhandenheit) and prior to any poetizing or fabricating what becomes available to manipulation (Zuhandenheit). This is precisely what enables us in our own way to be thrown into the world, to exist, to dwell, to speak and to understand (Arendt, 1996; Caputo, 1982; O'Leary, 1985). By saying this, I deliberately situate my own critical reflection "on the boundary", as it were, between a biblical theology and a political philosophical tradition which believes to understand and understands to believe with a view to engaging in social, ethical existence. Even though I fully subscribe to the Augustinian motto crede ut intelligas (Augustine, 1974, 19f., 23-25; 1984, 320f.), I believe with Pascal that "le Dieu d'Abraham, d'Isaac et de Jacob n'est point le dieu des philosophes" and agree with Spinoza in that conceptions of God have been historically and culturally conditioned, so 
that theological normativism often betrays the very political-institutional and empirical-naturalist components of a broader phenomenological account of religious beliefs.(Levy, 1991; Ricoeur, 1983) In this sense, Heidegger's dismissal of the idea of "Christian philosophy" as a "round square" serves also to translate any critical approach to ontotheology and to place it closer to Luther and Kierkegaard than to Augustine and Gilson. And yet Augustine remains for Western Christianity one of the greatest doctors of the Church and one of the richest sources of theological motifs for a Christian world-and-life view.

\section{Augustine's Conception of God}

In light of the deconstruction of metaphysics indicated above, Augustine is often criticized for at least two main metaphysical sins against ontology, namely, his doctrine of creatio ex nihilo and correlated conception of man as imago dei, in that both accorded a privileged place to a transcendent being outside, as it were, above the realm of phenomenal existence. Nevertheless the binary oppositions of "outside" / "inside," "superior" / "inferior," and the like, cannot be merely dismissed as "metaphysical" metaphors, especially when we take into account the biblical materiality of Augustine's hermeneutics. Although formally expressed in Latin terms that frequently translated Greek concepts, Augustine's texts were also interwoven with premetaphysical traditions which inform both the Hebrew Bible and its New Testament interpretations, regardless of known Hellenistic influences, esp. during the so-called Second Temple period. By saying this, I am not attempting at any sort of "purer," non-metaphysical thought, which might have flourished among certain ancient peoples before the Greek "contamination." The facile opposition of Hebrew, "concrete" thought to Greek, "abstract" thought has already been strongly criticized by biblical scholars and pos-Enlightenment critics of traditional Judeo-Christian orthodoxies, from James Barr and Jean Pépin to Levinas, Ricoeur, and Zarader (Barr, 1961; Pépin, 1958; 1976).

The main working hypothesis of this modest paper consists precisely in a textual attempt to do justice to both Heidegger's critique of metaphysics and the non-metaphysical, multi-genre poetics and intertwined narratives of biblical literature. Therefore, the biblical motif of "creation" and its imagery of the imago dei precede their very conceptualization as theological notions, visibly affected by Greek metaphysics. That is why any exposé of Augustine's conception of "God" cannot escape this hermeneutic tension between Jerusalem and Athens. "Theo-logy" denotes, after all, a rational discourse (Gk. logos) about "God" (theos), 
and in particular, the God of the Judeo-Christian Scriptures. If one starts reading the Book of Genesis and proceeds all the way throughout the Old and New Testament writings, one's view of theology will inevitably be informed by other biblical notions, such as the Near Eastern, mythical accounts of the creation of the universe and human beings, stories relating to their place in the cosmos, the revelation of God to His people and covenants, human relationships and human-divine relationship, holiness and sin, God's judgment and human responsiveness, curses and blessings, liberation, exile and diaspora, condemnation and redemption, servitude and freedom, hatred and love, etc. All these themes point to a view of theology which is much more comprehensive than theo-logy proper, in that it comprises not only a "comprehensive doctrine of God," but also an anthropology, a cosmology, a soteriology, a christology, a pneumatology, an eschatology, and so forth. Now, this systematic understanding of theological disciplines certainly betrays a historical, philosophical elaboration of thematized concepts in function of their biblical motifs, so that no doctrine is ultimately free of interpretations, as attested by numerous, competing views of Jewish and early Christian authors and traditions. It was indeed out of a hermeneutic network that Augustine developed his own theology, in light of his own understanding of the Scriptures, within an intellectual framework visibly influenced by Latin rhetorics and Neoplatonic philosophy, rabbinical and other Jewish traditions - remarking, en passant, his deficient knowledge of Hebrew and Greek - and in response to the theological heresies of Manicheans, Donatists, Pelagians, and others (Fredriksen, 2010; Agamben, 2011).

The Augustinian conception of God was thus articulated within the framework of his own experience of conversion to God and how this God was to be believed and understood in the Christian tradition. Although I won't examine Augustine's indebtedness to writers like Bishop Ambrose, rhetoric professor Marius Victorinus, and Neoplatonic philosophers Plotinus and Porphyry, we must keep in mind the metaphysical Sitz im Leben underlying the Augustinian formulation of theological concepts. For, as Heidegger has shown, one cannot conceive of any being who transcends (and precedes) either language (Sprache) or historicality (Geschichtlichkeit): concepts do not fall from heaven, they are linguistically and historically elaborated from below. Not even key words like "God" or "substance" have fallen from the skies like a meteor: as over against the Gnostics, Arians and Docetists, Augustine reaffirmed the true humanity of Jesus, in a christological credo that cannot be dissociated from the Nicaean doctrine of the Trinity, which is itself an elaborated revelation of God's personhood (Agamben, 2011). Moreover, the development of christological and trinitarian dogmas always presuppose an element of 
faith which must not be overlooked. In the last analysis, the self-revelation of God implies at the same time His incomprehensibility. Thence the insufficiency of theological concepts to express the mysterium fidei, which always exceeds one's own "belief" in God. For Heidegger, such an ontotheological, metaphysical belief had to be deconstructed (ab-bauen) in order to retrieve the primordial granting of the Being of beings, no longer as dogmatic "truth" (adequatio) but as a-letheia, which he equates with Ereignis (appropriating event, eventful unveiling) in the presencing of beings. For Dasein does not create Being but its being is the very existing locus for the unveiling of the Being of beings, as Dasein's ontical, factical existence is what makes the ontological possible(Levinas, 1967).

If I insist on averting a reductionist reading of Augustine, it is precisely because his theology as a whole cannot be reduced to its cosmology or to its anthropology, but every single thematic aspect of this theology, broadly construed, is linked to each other in a veritable doxological symphony. In fact, it has been my contention that such theological subdivisions stand or fall together and that the ultimate purpose of Augustine's theology is to glorify the eternal God and to make known His revealed work of redemption in Jesus Christ through the fellowship of the Holy Spirit, doing justice to the former's commitment to the Nicene and apostles' creeds. Augustine's trinitarian theology remains thus the cornerstone of his majestic literary opera. Even if the divine attributes (Being, Living, Knowing) could betray the Augustinian doctrine of the Trinity (esp. the Hebrew views of hokhma and ruach, respectively personified in the incarnated Verbum and Spiritus Sanctus), other triads could also be evoked in Augustine's own psychological accounts of the memoria, intelligentia and voluntas of God, so as to compromise the ontological weight of his theology. That is why I have chosen to focus on his doctrine of God, not only as I find it systematically formulated in the treatise on The Trinity, but also as it was poetically articulated with his own experience of conversion in the Confessions. In effect, I assume that Augustine's conception of God might help us thus to critically respond to the post-Heideggerian project of deconstructing onto-theology and its metaphysics of presence. For a metaphysics of presence can indeed be found in Augustine's texts on temporality, as in his conception of the "the three times" as "present" (Confessiones XI, 14, 15, 20), privileging presence over absence, or in the parousia (the apocalyptical, eschatological expectation of the advent or second coming of Christ) taken as ousia.

As Goulven Madec has rightly remarked in his preface to Mary Clark's translation of Augustine's Selected Writings, "Augustine's spirituality is nothing else than the ideal of the Christian life." (Augustine, 1984, xii). Because theology and spirituality go hand in hand, Augustine's own 
experience of a personal relationship with the triune God of Christianity cannot be detached from his theological understanding of the God revealed in the Scriptures. As Clark puts it, "in the Confessions we see his religious experience developing and in On the Trinity he reflects on the foundations of his spirituality." (Augustine, 1984, xvii). Augustine's doctrine of God certainly goes far beyond the contents of these two works, which I have selected for the strategic reasons expounded above. Before proceeding to study the Augustinian conception of God as substantia and caritas, it is worth briefly surveying some other texts dealing with his view of God. Following his conversion to Christianity in 386, Augustine's earliest concepts of God were outlined in De Beata Vita, De Ordine, and Soliloquia. In the Happy Life, Augustine asserts that the soul "is nearest to God" who, like the soul, is not corporeal (as the Manicheans believed) (Augustine, 1984, 169). God is also by nature the bestower of happiness for there is no happy life without God. Because God is eternal, "the secret sun" that "pours that beaming light into our inward eyes," we cannot be satisfied with anything less than the fullness attained in the possession of His wisdom: "For wisdom is nothing but the measure of the soul, that is, that by which the mind is liberated so that it neither runs over into too much nor falls short of fullness." (Augustine, 1984, 33). Although Augustine mentions Plotinus and the Academics and this Platonic terminology is very reminiscent of an ascetic gnosis, we must remark in passing that long before the Neoplatonic ascent toward the pleroma of the One, the Psalms and Proverbs of the Hebrew Scriptures already celebrated the fullness and the wisdom in the true knowledge of the One God, as exalted in the Shema, "Ha-Shem Eloheynu Ha-Shem echad" (Deut 6:4). In effect, Augustine's view of prevenient grace made enough room for a conception of God's revelation that did not exclude those who never acknowledged His works, for God's glory always precedes human understanding (Augustine, 1974, 189). The doxological tone of the De Beata Vita crowns Augustine's conception of theology as an invitation to prayer and praise before the Trinity:

This, therefore, is the complete satisfaction of souls, that is, the happy life: to know precisely and perfectly Him through whom you are led into the truth, the nature of the truth you enjoy, and the bond that connects you with the Supreme Measure! These three show to those who understand the one God, the one Substance, excluding the variety of all vain and superstitious images (Augustine, 1984, 169).

It is interesting to note that Augustine uses the word substantia so as to preserve the sacred truth of God from our human idolizing of the imago. In the De Ordine, which presents God as Creator and Sustainer, 
Augustine does equate the divinity with truth itself (I, viii, 23). That is why Augustine goes on to affirm that "the true, solid and sovereign authority is that which is called divine" (II, ix, 27) (Augustine, 1974, 27). Because God is the ultimate source of all truth, human finiteness cannot exhaustively comprehend the eternal nature of God, but God is actually understood through the negation of things known and revealed to us (II, vxi, 44; xvii, 46) This via negationis is inherent in Augustine's conception of God as mysterium, which underlies his spirituality, ecclesiology, and enlightened mysticism (Augustine, 1974, 151, 191, 205,226; 1984, 35-42, 201, 311, 364, 423-25). Finally, in the Soliloquies, Augustine praises again the authority of God, "the Father of truth" (deus pater veritatis), "the Father of wisdom" (sapientiae), "the Father of true and crowning life" (verae summaeque vitae), "the Father of blessedness" (beatitudinis), "the Father of that which is good and fair" (boni et pulchri), "the Father of intelligible light" (intelligibilis lucis), "the Father of our awakening and illumination" (evigilationis atque illuminationis nostrae), "the Father of the pledge by which I am admonished to return to Thee" (I, i, 2) (Augustine, 1974, 144). After praising the Framer and Sustainer of the universe, Augustine describes the nature of God in the following terms: "the one true and eternal substance" (una aeterna vera substantia), "where is no discord" (discrepantia), "no confusion" (confusio), "no shifting" (transitio), "no indigence" (indigentia), "no death" (mors), but where "is supreme concord" (summa concordia), "supreme evidence" (evidentia), "supreme steadfastness" (constantia), "supreme fullness" (plenitudo), "and life supreme" (vita). "Where nothing is lacking" (deest), "nothing redundant" (redundat). "Where Begetter and Begotten are one" (est). And Augustine addresses to his God not only as a personal deus and pater, but also as domine, rex, causa, spes, res, honor, domus, patria, salus, lux and vita (Augustine, 1974, 146). There are many other passages where Augustine names an enormous variety of attributes to describe the nature of God. One may think particularly of De Libero Arbitrio, De Vera Religione and De Civitate Dei, which all articulate theo-logy with anthropology, cosmology, and eschatology. In effect, as I have indicated, Augustine's philosophy of history and his practical theology of Christian living cannot be dissociated from his conception of God. Since I must focus on the ontological implications of Augustine's theo-logy, I conclude this section with some remarks that shall introduce us to the metaphysical problematic of his substantialist view of God (Marion, 1982).

In the first place, we observe that Augustine exalts and praises the Being of God for the excellence and greatness of His attributes. There is not one single attribute invoked by Augustine which is not explicitly or implicitly found in the Bible. The idea of God as Supreme Being and 
as the utmost expression of fullness may thus be regarded as the best formula to define the Augustinian conception of God: a "God to which nothing is granted to be superior" (De Libero Arbitrio II, vi, 56). The ontological weight of this definition would become clearly expressed by Anselm in his famous Proslogion ("aliquid quo nihil maius cogitari possit," 2), although it was not until Kant that the "ontological argument" acquired the "ontological" sense assigned to this term - for the term ontologia was coined by scholastic writers in the seventeenth century. In order to avoid anachronistic charges against Augustine's view of God, it would be more appropriate to understand such an "ontological weight" in the very scriptural sense attached to the divine names HaShem (YHWH, the Tetragramaton), Elohim, and Kyrios, which all denote the omnipotence, omnipresence, and omniscience of the Eternal Lord. Without succumbing to a facile biblicism, we must parenthetically remark that the famous passage of God's self-revelation to Moses in Exodus 3:14, which Augustine and other exegetes often regarded as an expression of the esse-deus couple, remains in fact mysterious and problematic. Etienne Gilson, among others, has shown the difficulties of a grammatical interpretation of what he calls "la métaphysique de l'Exode" (Gilson, 1949, 27). On the other hand, the Vulgate translation of the Hebrew as ego sum qui sum not only misses the play on words (on God's Holy Name, Ha-Shem, reminiscent of the verb "to be" in the past, present, future-hayah, howeh, yihyeh), but also obfuscates the incompletion of the Hebrew verb which may indicate the personhood of the One who wills. Perhaps "I am who I will (to) be" would be a much better translation for the Hebrew ehyeh asher ehyeh. In any case, the "ontological weight" of Augustine's interpretation of God's name as Being (esse, nomen est incommutabilitatis) —for instance, in Sermo VII, 7, De civitate dei XII, 2- is strongly supported by Old Testament writings. Indeed, Vulgate variants refer back to the Septuagint usage of the word kavod ("glory, honor") and shekhinah ("dwelling") in Hebrew literature, essentially expressing the character of Who God is (literally, His weight) and the presence of Ha-Shem among His people of Israel (cf. Ex 33:1834:8; 40:34-38; 2 Chr 7:1-3; Isa 6:1-5; 44:23; Ezk 1:27-28; 8:4; 9:3; 43:2; Ps 29:3). This Semitic, literary sense is interestingly found in one of Paul's epistles to the Corinthians: "For our light and momentary troubles are achieving for us an eternal glory that far outweighs them all" (2 Cor 4:17; my emphasis). Kavod also refers thus to the glorious divine presence and to the particular place of this presence, namely, the altar of Israel's God in His temple in Jerusalem. Paul could claim that to the Israelites "belong the glory (doxa), the covenants (diathêkai), the giving of the Law (nomothesia), and the worship (latreia), the very essence of the 
Torah (Romans 9:4). That is why the New Testament focuses on the Incarnation of Christ as a revelational expression of God's glory: as John says in the prologue, the incarnate Word of God "tabernacled" among us (Gk. eskénosen, an obvious Semitism which also shows that the Greek skéné, "tent, stage, scene," is linguistically related to the Hebrew shakhan, "to dwell-in tents," also akin to Shekhinah, the Presence of Ha-Shem): "We have seen His glory, the glory of the one and only Son, who came from the Father, full of grace and truth" (Jn 1:14). Thus Augustine's doxological conception of God's being attains full expression in the metaphysics of presence that governs his christology, as we find it in the Homilies on the Gospel of John (Augustine, 1984, 265-93). But there remains the ontological challenge of accounting for an intimate combination of two substances (divine and human) in the Incarnated Son of God.

Now, to affirm God as esse, to say that God is, as opposed to non esse and to an evil privation of being, means for Augustine not only that God is truly the highest being, but also that God is the summum bonum, the Supreme Good (Augustine, 1974, 147). What is at issue in this case is the perfection of Being, in that God is essentially viewed as an infinitely perfect being, without any clear distinction between esse and ens. If every other being can become less good because of their imperfection, God alone is the "highest and immutable Good" which does not undergo any becoming, but always remains identical to His own nature and substance. Speaking of this ontic relation of the bonum between a perfect Creator and His finite creation, Augustine says in the De Libero Arbitrio:

Every nature, moreover, is either corruptible or incorruptible. Every nature, therefore, is good. I use the word "nature" for the more usual word "substance." Every substance, therefore, is either God or from God, since every good is either God or from God (Augustine, 1984, 117).

\section{De Trinitate: God as Substantia}

The use of philosophical terms such as natura and substantia indicates some of the linguistic difficulties involved in early Christian theo-logy. The Latin substantia may be regarded as the equivalent of the Greek word hyspostasis, which means "an objective reality capable of acting," and its usage was determined by Tertullian, who employed it to refer to what philosophers usually called ousia ("essence," "being"). The trinitarian controversy over the two natures of Jesus Christ was resolved by affirming the full divinity of the Son as "of one substance" (homoousios)

Veritas | Porto Alegre, v. 62, n. 2, maio-ago. 2017, p. 330-353 
with the Father, in the Council of Nicaea, in 325 (Agamben, 2011). It is beyond the scope of the present paper to explore the developments of the doctrine of the Trinity and its christological and pneumatological implications, which are certainly reflected in Augustine's own theology. For Augustine inherited Tertullian's theology, as we can infer from his masterly opus On the Trinity, composed between 399 and 419. In fact, the problem of "speaking about God" constitutes one of the main features of De trinitate as it deals with analogies, metaphysical concepts, and philosophical-theological thematization. Because of the hermeneutic concern of the present study I shall focus on Augustine's conception of God as substantia and its ontological implications.

Augustine begins his treatise De Trinitate by refuting three erroneous attempts to think about God, viz., to transfer human ideas of corporeality to the divine, to deduce the spiritual substance from the human soul, and to "transcend the whole of creation," as if this were possible, "in order to fix their attention on the unchangeable substance which is God" (De trinitate I. i. 1) (Augustine, 1984, 314). Augustine is thus presupposing, from the outset, that God must be conceived as substantia, and he proceeds to argue from the Scripture that, although expressed in human language, God is unique and the divine substance not only ultimately transcends everything human -including our thoughts and beings- but has made the humanum itself possible through immanent revelation. The very being of God is therefore biblically expressed in terms of the trinitarian revelation of the Father, the Son, and the Holy Spirit:

Therefore, with the help of the Lord our God and as far as lies in our power, we shall endeavor to give an explanation of that very thing which they demand, namely, that the Trinity is the one, only, and true God, and that one rightly says, believes, and understands that the Father, the Son, and the Holy Spirit are of one and the same substance or essence (De trinitate I. ii. 4; Augustine, 1984, 313).

Because, as the Apostle Paul said, "we see now through a mirror in an enigma" (I Cor 13:12), Augustine cannot but use figurative language to develop a biblical doctrine whose incomprehensibility must be assumed from the very beginning (De trinitate XV.ix.15). Two trinitarian enigmas are thus to be recognized at this point: ad intra, the substantial unity of the three persons does not nullify their individual distinction, and, ad extra, the revealed Trinity belongs to an economy of salvation which cannot be separated from the triune God a se (I.i.7-8). In effect, the greatest contribution of Augustine's work to the dogma of the Trinity is the inherently necessary interior relationship of the divine persons with one another. That is why God must be affirmed as Trinity, from the outset, 
at a primordial level which might have been defined as "ontological." Despite the enigmatic character of this conception and in spite of the limitations of human language, Augustine boldly says of God the Trinity:

But God is without a doubt a substance, or perhaps essence would be a better term, which the Greeks call ousia. For just as wisdom is so called from being wise, and knowledge is so called from knowing, so essence (essentia) is so called from being (esse). And who possesses being in a higher degree than He, who said to His servant Moses: "I am who I am," and "He who is, has sent me to you" (De trinitate V.ii.3).

And Augustine goes on to explain that essentia or substantia, whenever applied to God, is not susceptible of accidents. This means that, in Aristotelian terminology, what Augustine regards as God's substantia corresponds to an ousia proté (substantia prima), an individual being without predicates and which is not the predicate to any other being, that is, the subject par excellence, as opposed to the subject of a proposition (the ousia deutera). Hence the immutability and the permanence of God's substantia. No wonder Augustine's appropriation of the Latin ego sum serves to contrast an eternal, unchangeable God with His temporal, becoming creation. It seems that God's substantia acquires thus an archetypal meaning vis-à-vis the beings of His created cosmos:

But all other things that are called essences or substances are susceptible of accidents, by which a change, whether great or small, is brought about in them. But there can be no accidents of this kind in God. Therefore, only the essence of God, or the essence which God is, is unchangeable. Being is in the highest and truest sense of the term proper to Him for whom being derives its name. For what undergoes a change does not retain its own being, and what is subject to change, even though it may not actually be changed, can still lose the being which it had. And, therefore, only that which is not changed, but cannot undergo any change at all, can be called being in the truest sense without any scruple (De trinitate V.ii.3).

Strictly speaking, according to post-Thomistic scholaticism, substance may be said to be composed of two principles, essence (essentia) and an act of being (esse), the former being related to esse as a potency, and the latter being related to essentia as an act. Essence (essentia) is the proper potency of the act of being (esse) and together with this act constitutes the substance (substantia). "Essence confers upon this substance a specific manner of being and is defined as that by which a thing is what it is, that through which and in which a being has its 
act of being (esse) (Aquinas, De Ente et Essentia). Essence pertains truly and properly to substance while it pertains to accidents only in a qualified sense." (Horrigan, 2007, 27). Augustine had not yet sorted out such nuanced distinctions between esse, ens, substantia, and essentia. If we are to do justice to Augustine's hermeneutics, we must take into account his Neoplatonic apprehension of the conceptualization of New Testament revelation and its interpretation by the early Church Fathers, when Christian theology was still emerging in its autonomy vis-à-vis Greek philosophy and Jewish religion. It is enough to recall that, although Augustine was deliberately using the word substantia to translate the Greek ousia, he did not know in what exactly consisted the semantic passage from hypostasis to substantia (De trinitate V.viii.10). In effect, it was only upon the Council of Chalcedon, which was held in 451, twenty-one years after Augustine's death, that hypostasis became the general term to designate no longer the "substance" (as opposed to the essence), but the "person" (as opposed to both substance and essence) in the trinitarian confession (mian ousian, treis hypostaseis, "one essence/substance, three persons"). It is of utmost importance, therefore, to emphasize the materiality of Augustine's conception of the Trinity as substantia, in that his subject-matter, the Sache of his theological investigations was aiming not so much at the "essential" nature of God as at the "relational" character of His personhood. God's being is thus a priori equated with His being three persons, being great, being good, being love. As Augustine summarily put it,

To sum up: whatever is spoken of God in respect to Himself and of each single person, that is, of the Father, the Son, and the Holy Spirit, and together of the Trinity itself, is to be predicated in the singular of each divine person and not in the plural. For God, to be is not one thing, and to be great another thing; on the contrary, for Him to be is the same as to be great. Therefore, just as we do not speak of three essences, so we do not speak of three greatnesses. I give the name essence to what the Greeks call ousia, but which we more generally designate as substance (De trinitate V.viii.9).

We must concede thus that Augustine's substantialist language, although clearly tainted with Neoplatonic and metaphysic motifs, sought to express a relational, existential dimension of personhood which was not yet formally established in Christian orthodoxy. Even the metaphysical dichotomy between subject and object, which would be later consolidated by Descartes's rationalism and Kant's idealism, was certainly already present in Augustine's theologia gloriae, but his view of both "subject" and "conscience" was rather analogical than 
ontological, as can be inferred from his trinitary variations. For Augustine insisted on the differential separation of the substantia of the Creator from His created substantiae, at the same time that he maintained a relational participation at work in the restoration of the imago dei. To speak of God as substantia was, after all, a limited way of expressing the essential perfection of God's being: "For He is truly alone, because He is unchangeable." (De trinitate VII.v.10). Augustine went so far as to admit that the term substantia was not "appropriate" in itself to translate the untranslatable mysterium dei: it was only "more appropriate" than other linguistic formulations, but God's self-revelation always already implies His incomprehensibility. One arrives inevitably at the so-called "hermeneutic circle" of transcendental reasoning, which characterizes one of the greatest problems of theo-logy. On the one hand, we have seen that speaking about God as substantia betrays the very via negativa of a theological discourse that resists idolatry and ontological identity. As Joseph O'Leary has convincingly shown, a metaphysics of presence seems to be inherent to Augustine's definition of God as "substance" or "being," in that the re-presentation of the economic Trinity functions as a transcendental signifier of an ontological signified, namely, the trinitarian Being a se (O'Leary, 1985). On the other hand, as we seek to do justice to the conceptual framework of Augustine's theology, the ambiguity of his appropriation of a substantialist terminology lead us to question the possibility itself of a revelational language of faith, as the functions or roles played by the trinitarian persons could betray a certain reduction of the Holy Spirit to a donum and especially to the caritas between the Father and Son (Kuehn, 2007, 576). These hermeneutical paradoxes are also revealing of the tension between his takes on freedom of the will and what has been known as political Augustinianism, being differentiated from a political theology (including thus his theology, sive philosophy, of history) and from Augustine's conceptions of social freedom, institutions, government, Church and State relations, social and political theory overall.

\section{The Confessions and the Personal God of Love}

As over against the "God-Substance" of De Trinitate, O'Leary found that in the Confessiones Augustine's conception of an experiential, dialogical "God-Spirit" avoids the ontological pitfalls of a metaphysics of presence. The metaphysical, conceptual theologizing of De Trinitate is thus contrasted with the contemplative, biblical metaphorics of the Confessiones. A biblical poetics of spiritual conversion cannot after all be systematized into theological concepts and metaphysical thoughts. 
Although this comparative approach still has its merits and it was indeed what motivated us to work on this topic, O'Leary has already retracted that original thesis, as he radicalized his attempt at a "deconstruction of theology" by "overcoming Augustine." In his own words,

The Bible as opposed to metaphysics is quickly enlisted for a series of roles within the discourse of metaphysics-God as "infinite," "other," "Thou" is still represented as a set of principles. Still less does an appeal to contemplative experience provide a foothold for overcoming Augustine, for his own control of every nuance of such an appeal is not to be bettered and, in fact, the language of immediate experience, the language of Spirit, in the Confessions powerfully reinforces Platonic ideals of presence, interiority, certitude, and recollection (O'Leary, 1985, 166).

O'Leary proceeds to reaffirm the textual superiority of the Confessions vis-à-vis other theological writings, precisely because of the metaphorical over-determination of meaning of the latter, in that the usage of terms like substantia and esse in that literary work always "transcends the strictly metaphysical sense of these words." (O'Leary, 1985, 166). Although this cannot be meant as a textual, literary criticism of Augustine's most acclaimed opus, I shall explore here its particular feature of metaphoricity as applied to the conception of God. By "metaphoricity" I simply mean the textual production of meaning by continuously "trans-ferring" (Gk. metaphorein) the meaning of one thing into another, especially in analogical structures of signification, as they are privileged in Augustine's narratives. One of the greatest philosophical contributions of the Confessiones is indeed related to the problem of language as it would be later explored by hermeneutics. The fact that Martin Luther's experiential view of the "Word of God" was to a great extent the outgrowth of an Augustinian tradition only confirms the impact which biblical hermeneutics would exert upon modern hermeneutics, as we can infer from the pioneering work of Friedrich Schleiermacher. In a passage from the Confessiones made famous by Wittgenstein's Philosophical Investigations (Part I, 1-3, passim), Augustine describes his own appropriation of language, from the "state of infancy" when he "could not speak" to the time when he "first learned to speak":

non enim docebant me maiores homines, praebentes mihi verba certo aliquo ordine doctrinae sicut paulo post litteras, sed ego ipse mente, quam dedisti mihi, deus meus, cum gemitibus et vocibus variis et variis membrorum motibus edere vellem sensa cordis mei, ut voluntati pareretur, nec valerem quae volebam omnia nec quibus volebam omnibus (Confessiones I, 8). 
Although this is not a theoretical account, Augustine's conception of "words" as the meaningful expression of "things" is interestingly articulated with his own experience of learning a language as a child. According to this classic view, the meaning of a "word" corresponds to an original "thought" about a "thing" or to the meant "thing" itself, brought into the presence of the mind by speaking, remembering, imagining, writing, etc. We see in the passage above that Augustine's conception of language presupposes some "primordial language" (verbis naturalibus) which enables the child to learn any other language, as if the child were naturally capable of thinking even before speaking. Of course, what Augustine sought to emphasize in his view of language is the fact that human beings can speak (and think) only because they have been created in the image and likeness of the trinitarian God who reveals Himself through His Word (the Father speaks in the Old Testament), in His Word (the Son fulfills what was to be known in the New Testament) and within the procession of His Word (the Spirit proceeds from both the Father and the Son, in the most perfect expression of love). Analogous to the revelation of the Eternal Word, Augustine's semantic theory in De Trinitate discloses three senses assigned to the verba:

For we use the term "word" in one sense, when we speak of words which fill a determinate space of time with their syllables, whether they are spoken or simply thought; in a different sense, when everything that is known is called a word impressed on our mind, as long as it can be brought forth from our memory and defined, even though the thing itself displeases us; and in still another sense when that which is conceived by the mind pleases us (De trinitate IX.x.15).

\section{And he goes on to say}

We conclude from this that, when the mind knows itself and approves what it knows, this same knowledge is in such way its word, that it is wholly and entirely on a par with it, is equal to, and it is identical with it, because it is not the knowledge of a lower essence, such as the body, nor of a higher essence such as God. And since knowledge has a likeness to that thing which it knows, namely, that of which it is the knowledge, then in this case it has a perfect and equal likeness, because the mind itself, which knows, is known. And, therefore, knowledge is both its image and its word, because it is an expression of that mind and is equalled to it by knowing, and because what is begotten is equal to its begetter (De trinitate IX.xi.16).

\section{Conclusion}

Although an erotic, Platonistic epistemology may well be detected in Augustine's hermeneutics, we must stress, once again, the biblical 
materiality of his thought, as we can infer from such a rapprochement between "love" and "knowledge" (e.g., Gen 4:1; Jos 23:14; Jer 1:5; Hos 11:1; Jn 10:14,27; Rom 9-11; Phil 3:10; 1 Jn 2:3-6; 3:16-19; 4:7,8). If an "inward locution" is opposed to its verbalized, signifying "word," it is not simply because Augustine borrowed an ascending metaphysics of presence from Neoplatonism, but above all because of his interpretation of the temporal-historical, salvific motif in the Bible. For Augustine, the imago dei remains the governing metaphor of his entire theology, as we find it poetically articulated with his own experience of conversion in the Confessions. The "outside-inside" dichotomy is thus best expressed in terms of "turning away" (aversio) or "turning toward" (conversio) the True and Supreme Good, as we find it, for instance, in Confessiones V.ii.37. The "narrative time" of the Confessiones is revealing for a theological understanding of "historical time," as Augustine often speaks of a "before" and an "after" vis-à-vis the conversion of the fallen imago dei. Just like there was a supralapsarian and an infralapsarian time in human history ("before" and "after" the Adamic fall), so there must be an experience of conversio which reverses the tragic fate of the sinner as he/she turns back to the Creator (Principium) through the reconciliatory work of His Son (Similitudinem) and by the gift of His Spirit (Donum). ${ }^{3}$ Since the fall, the imago dei has been so corrupted that human beings have been living "far off" from the Creator, as it were, "in the region of utter unlikeness" (regione dissimilitudinis) (Confessiones VII, 10). Christ appears then as the mediating Word between God and humans, the only perfect Sign in an imperfect world of signs and words. We conclude thus that Augustine's conception of God cannot be separated from his language of self-understanding and its "hermeneutics of conversion." If his trinitarian hermeneutics was visibly inspired by Platonistic triads, the Augustinian motif of creation-fall-salvation may as well be regarded as a biblical one (a Christian variant of the Jewish creation-revelation-redemption motif), and these two are so intimately associated that it would be unfair to characterize Augustine's thought in exclusivist, simplistic terms.

There is no doubt that the experiential, metaphorical language of the Confessiones depict God in a rather personal, relational way, in contrast with the metaphysical, theological substantia of De Trinitate. On the other hand, as already indicated above, the substantia of the Trinity was itself to be understood in its mysterious personhood, and there is one passage in the Confessions (VII, 17) where Augustine explicitly speaks of "the unchangeable" not as the ego sum but as an id quod est, which sounds somewhat impersonal and essential. Nevertheless, the conception of

\footnotetext{
3 De vera religione LV, 113.
} 
God as "Thou" (tu) and "mine" (deus meus) prevails throughout the Confessiones, where the dramatic struggle of humans with God and their own fallen, fatal condition is poetically resolved by the triumph of God's grace and love over sin and imperfection: Augustine's teleological theology of history points, after all, to the redeeming victory of God's ecclesia over the original sin which tainted human condition.(Marrou, 1968) The triumph of the self-revealing God of gratia and caritas is precisely what distinguishes Augustine's conversion to the Word of Life (Confessiones VII,9) from his earlier conversion to Greek philosophy (Confessiones III,4; VII,20,21). For Augustine's hunger and thirst for the truth was only satisfied when he started receiving the spiritual nourishment from the Bible (Confessiones III,5), which was decisive for his subsequent refusal of Manichaeism (Confessiones III,6,7). It was in the Scriptures that Augustine discovered that "God is Spirit, and His worshipers must worship in spirit and in truth" (Jn 4:24). The nature of this God, His attributes, and the benefits of His being (fruitio dei) denote together the object of that profound desiderium which Augustine was passionately seeking to know and love in his life:

quid est ergo deus meus? quid, rogo, nisi dominus deus? quis enim dominus praeter dominum? aut quis deus praeter deus nostrum? summe, optime, potentissime, omnipotentissime, misericordissime et iustissime, secretissime et praesentissime, pulcherrime et fortissime, stabilis et incomprehensibilis, inmutabilis, mutans omnia, numquam novus, numquam vetus, innovans omnia ...colligens et non egens, portans et implens et protegens, creans et nutriens, perficiens, quaerens, cum nihil desit tibi (I, 4).

All these characteristics could be essentially assimilated into the single conception of God as substantia, in particular the immutability of God: "nam tu semper idem, quia ea quae non semper nec eodem modo sunt eodem modo semper nosti omnia" (VIII,3). It seems however that Augustine often shifts from an "ontological" speculation about God (an sit, quid sit) towards a "revelational" theo-logy (quale sit), which constitutes the peculiar "personal" dimension of his biblical anthropology (Confessiones X.x.17). Thus, after the substantialist description of God's being in the quotation above, Augustine goes on to add:

amas nec aestuas, zelas et securus es; paenitet te et non doles, irasceris et tranquillus es, operas mutas nec mutas consilium; recipis quod invenis et numquam amistisi; numquam inops et gaudes lucris, numquam avarus et usuras exigis. ... et quid diximus, deus meus, vita mea, dulcedo mea sancta, aut quid dicit aliquis, cum de ti dicit? et vae tacentibus de te, quoniam loquaces muti sunt (Confessiones I, iv). 
One seems to have been caught up in the hermeneutic undecidability between saying too much about a wholly-other God (deus absconditus) and saying nothing at all in response to His intelligible revelation (deus revelatus). Interestingly enough, Augustine set out to theologically articulate this mysterium by proposing an intellectus fidei between the naive doxa and the scepticism of the pagans (Confessiones VI,5). His contemplative theology emerges thus out of his personal experience with God, "which the eye of the flesh cannot ken, it being only by the inner man to be discerned" (Confessiones VI,16). It is only in a living, personal relationship with God that any discourse about God makes sense: to know God's character (quale) means, for Augustine, to be loved by God, to love Him, and to love our fellow creatures as we love ourselves. In a nutshell, to know God is to know the meaning of love: "Whoever does not love does not know God, because God is love" (1 Jn 4:8). Since Nygren charged Augustine of having confused agapé and eros with a hybrid of both, many scholars have questioned the biblical value of Augustine's conception of caritas. ${ }^{4}$ It is impossible for me to explore this delicate question here, but I confine myself to simply saying that, if on the one hand, it might seem that caritas as such cannot fully "ground" an ontological argument in that love remains an ontic expression of humanness, on the other hand we must follow a via negativa of "alterity" in order to do justice to the "other-ness" of God, which cannot be understood but only received as the gift of love, in its full givenness. It is precisely in this second sense that I think Augustine's conception of God as caritas to constitute a powerful, provocative metaphor in theology and better suitable than substantia for the ground of Being. Even if we conceive of love as an ontic, human expression of feeling, emotion, empathy, and profound moral sentiment, it always exceeds our own human-ness or everything we claim to understand as human: love may serve to define our deepest longings, and yet we always fall short of it because we never love enough.

Furthermore, caritas turns out to be a valuable currency for interfaith exchanges, particularly for the Jewish-Christian dialogue and their recent developments in their respective contributions to an ethics of alterity, reciprocity, and solidarity. Although Augustine ends up subordinating Judaism to Christianity, anticipating Lutheran, Hegelian, and dispensationalist misreadings of covenant theology (namely, that the new covenant superseded the old covenant because it reveals itself as the spiritual fulfillment of God's grace in the history of salvation), Fredriksen has convincingly argued that his was a theological

4 Cf. Anders Nygren, Agape and Eros, trans. P. Watson, Philadelphia: Westminster Press, 1953. 
construct rather than a pastoral or practical anti-Jewish attitude, as the ones shared by supersessionists and most of his predecessors and contemporaries:

Because of the way that Augustine reads the Bible and understands the significance of the Jewish people, I argue, the question fundamentally collapses. Augustine's "Jew" is indeed a biblical tupos figuring catholic doctrinal truths. But because Augustine reads the Bible ad litteram and proprie - "historically" - he conceives the two Jewish communities, biblical and contemporary, as one. No less than the people chronicled in the church's Old Testament, the Jews of the late Roman synagogue, for Augustine, embody - literally incarnate - the will of God in human history. The continuing existence of Jews as Jews, Augustine urges, is yet another gracious gift of God to the church (Fredriksen, 2010, 372).

In the same vein, Arendt's Love and Saint Augustine provides us with a particularly provocative glimpse into the implied, but rarely articulated, context of a phenomenology of sociality and the moral ground for action in the public realm. In Arendt's own words, "the decisive fact determining man as a conscious, remembering being is birth or natality, that is, the fact that we have entered the world through birth." (Arendt, 1996, 51). The social, intersubjective dimension which was missing in Heidegger's existential account can be thus recovered. According to Arendt,

Man is the other, whether he understands himself as an isolated individual or as conditioned and essentially constituted by the fact of belonging to the human race. The fact that the two questions are connected is made even clearer by the insight into their specific conjunction, which is derived from the doctrine of neighborly love. It is a twofold conjunction. Although we can meet the other only because both of us belong to the human race, it is only in the individual's isolation in God's presence that he becomes our neighbor. By virtue of this isolation in God's presence, the other is lifted out of the self-eviden dependence in which all people live with each other, and then our connection with him is subject to the explicit obligation of kinship. Second, however, the possibility of isolation enters as a fact into the history of the human race and thus comes to be historical itself. According to Augustine's philosophy of history, before salvation through Christ, there was only the human race determined by Adam. Moreover, it is the very possibility of isolation that enables us to detach ourselves from human history and from its irrevocable enchainment by generation (Arendt, 1996, 112).

In effect, Scanlon reminds us that it was, after all, from Augustine that Arendt created her central metaphor, "natality," as Augustine overcame the Greek understanding of cyclical time with his insistence that the Incarnation was the radical novum in history, the free source of new 
beginnings, initium ut esset, creatus est homo, ante quem nemo fuit (that a beginning be made, humans were created). Natality is empowered by caritas rather than mortality as the spring of action, as Arendt employed Augustine to go beyond her mentor, Heidegger (Caputo, 2005, 159). The limit-experience of one's own death opens up the horizon for the encounter with the Other, as Derrida, one of "two boys from North Africa who made it big in Europe" - to recall Rorty's felicitous formularecasts the praxis of confession as a cutting b'rit, a circumcision, a covenant and alliance with the Wholly-Other:

One confesses the other. Even if I confess myself, if I confess having done this and that, I am confessing another one. That's the structure of confession. I cannot confess myself. If I confess that I did so and so, that is the other. That is already the other I'm confessing. I make the other confess the crime; otherwise, I couldn't confess. There is this division, this divisibility of the confession which structures the confession, so that I never confess myself. A confession is never mine. If it were mine, it wouldn't be a confession. It is always the other in me who confesses. This is consistent with something I tried, after having written "Circumfession," again and again to reaffirm, namely that a decision is always passive and a decision of the other. This is something no philosopher as such can legitimate, can accept, that a decision is passive. That is a scandal in philosophy, a passive decision, but decision is passive. It's the other who decides in me. It is always the other who makes the decision, who cuts-a decision means cutting (Derrida, 1993; Caputo, 2005, 38).

Just as authentic compassion is the working out of caritas, of an ongoing, resilient praxis that challenges every theoretical orthodoxy and every theo-logical confession, so is the meaning of Augustine's prayer and confession to the Wholly Other, coram deo, as the name of God itself, Ha-Shem, draws us outside the closed circle of being and truth into an open space without borders, where tears are shed beyond being. As Caputo put it so well,

The meaning of the name of God in deconstruction never comes down to a decision made in the order of being or knowledge, to deciding whether or not God exists; its meaning is shifted out of the circle of knowing and non-knowing, concealment and non-concealment, being and non-being, and located in a "logic or a topic" that is otherwise than knowing, in a sphere of tears au-delà de l'être. That is the order of the tallith, not of the veil; of the call for justice, not an inquiry into truth; the order of the heart, of blood, of faith, of circumcision, not of creedal propositions; the order, not of knowing but of doing the truth (facere veritatem); the order, not of things but of the event. Its meaning is not nominative, to pick out and name something somewhere, but invocative and provocative, to make something happen (Caputo, 2005, 98). 
N. de Oliveira - Deconstructing the substantialist conception of God

\section{References}

Agamben, Giorgio. The kingdom and the glory: For a theological genealogy of economy and government. Trans. Lorenzo Chiesa and Matteo Mandarini. Stanford University Press, 2011.

Arendt, Hannah. Love and Saint Augustine. Edited and with an interpretive essay by Joanna Vecchiarelli Scott and Judith Chelius Stark. University of Chicago Press, 1996. [Der Liebesbegriff bei Augustin, 1929].

Augustinus, Aurelius. Corpus Christianorum: Series Latina, v. 27-59. Turnhout: Brepols, 1953.

. Patrologia Latina. Paris: Migne, 1841-42.

. Confessions, 2 v. Tradução de William Watts. The Loeb Classical Library. Londres: Heinemann, 1968.

. Augustine of Hippo: Selected Writings. Trans. Mary T. Clark. Nova York, Ramsey \& Toronto: Paulist Press, 1984. 1974.

. The Essential Augustine. Edited by Vernon J. Bourke. Indianapolis: Hackett,

. On Free Choice of the Will. Trans. Anna Benjamin and L. H. Hackstaff. Nova York: Macmillan, 1964.

Barr, James. The Semantics of Biblical Language. Oxford University Press, 1961.

Brown, Peter. Augustine of Hippo: A Biography. Berkeley/Los Angeles: University of California Press, 1967. Revised Edition, 2000.

Caputo, John D. and Michael J. Scanlon, editors. Augustine and postmodernism: Confessions and circumfession. Bloomington, IN: Indiana University Press, 2005.

. The Mystical Element in Heidegger's Thought. Athens: Ohio University Press, 1978. Revised, paperback edition with a new "Introduction". New York: Fordham University Press, 1986.

. Heidegger and Aquinas. Fordham University Press, 1982.

Coyne, Ryan. Heidegger's Confessions: The remains of Saint Augustine in Being and Time and beyond. The University of Chicago Press, 2015.

Derrida, Jacques. "Circumfession," in Geoffrey Bennington and Jacques Derrida, Jacques Derrida, trans. Geoffrey Bennington. Chicago/London: University of Chicago Press, 1993 [1991].

Fredriksen, Paula. Augustine and the Jews. A Christian defense of Jews and Judaism. New Haven, Conn.: Yale University Press, 2010.

Gilson, Etienne. Introduction à l'étude de saint Augustin. 2e éd. Paris: Vrin, 1943.

. "Propos sur l'être et sa notion," San Tommaso e il pensiero modemo, ed. Antonio Piolanti. Citta Nuova: Pontificia Academia Romana de S. Tommaso d' Aquino, 1974.

Heidegger, Martin. Being and Time. Translated by John Macquarrie and Edward Robinson. New York: Harper \& Row, 1962. Press, 1982.

The Basic Problems of Phenomenology. Bloomington: Indiana University . Sein und Zeit. 16th ed. Tübingen: Niemeyer, 1986. 
. Phenomenology of the Religious Life. Translated by Matthias Fritsch and Jennifer Anna Gosetti-Ferencei. Bloomington: Indiana University Press, 2004.

. Gesamtausgabe. Frankfurt am Main: Vittorio Klostermann, 1976.

Horrigan, Paul Gerard. God's Existence and Other Philosophical Essays. Lincoln, NE: iUniverse, 2007.

Jonas, Hans. Augustin und das paulinische Freiheitsproblem. Eine philosophische Studie zum pelagianischen Streit. 2nd ed. Göttingen: Vandenhoeck \& Ruprecht, 1965 [1930].

Kuehn, Evan F. "The Johannine Logic of Augustine's Trinity: A Dogmatic Sketch". Theological Studies 68 (2007), p. 572-594.

Levinas, Emmanuel. En découvrant l'existence avec Husserl et Heidegger. Paris: Vrin, 1967.

Levy, Ze'ev. Baruch Spinoza: Seine Aufnahme durch die jüdischen Denker in Deutschland. Stuttgart, 2001.

. Spinoza and the Concept of Judaism: A concept and its influence on Jewish Thought. Tel Aviv, 1972 (Hebrew), 2nd ed. 1983; 3rd ed. 1991.

Marion, Jean-Luc. Dieu sans l'être. Paris: Fayard, 1982.

Marrou, Henri-Irinée. La théologie de l'histoire: Augustinus Magister. Paris: Cerf, 1968.

. St. Augustin et l'augustinisme. Paris: Seuil, 1955.

O'Leary, Joseph Stephen. Questioning Back: The Overcoming of Metaphysics in Christian Tradition. Chicago: Winston Press, 1985.

Pépin, Jean. Mythe et allégorie. Paris: Éditions Montaigne, 1958.

. Saint Augustin et la dialectique. Villanova University Press, 1976.

Ricoeur, Paul. Temps et récit, 3 v. Paris: Editions du Seuil, 1983-85.

Stump, Eleonore and Norman Kretzmann, eds. The Cambridge Companion to Augustine. Cambridge University Press, 2001.

von Herrmann, Friedrich-Wilhelm. Augustine and the Phenomenological Question of Time [Augustinus und die Phänomeologische Frage Nach der Zeit]. Lewiston: Edwin Mellen Press, 2008.

Zarader, Marlène. La Dette impensée: Heidegger et l'héritage hébraïque. Paris: Seuil, 1990.

\section{Endereço postal:}

Programa de Pós-Graduação em Filosofia - PUCRS

Av. Ipiranga, 6681, prédio 5

Porto Alegre, RS

Data de recebimento: $10-08-2017$

Data de aceite: 06-09-2017 